\title{
WAKAF DI INDONESIA \\ POTENSI DAN CARA PENYELESAIANNYA MENURUT PERATURAN PERUNDANG UNDANGAN
}

\author{
Yusna Zaidah
}

Fakultas Syariah dan Ekonomi Islam IAIN Antasari, Jl. Jenderal Ahmad Yani Km 4,5 Banjarmasin

Email: Yusnazaidah@ymail.com

\begin{abstract}
This paper will discuss the potential and endowments dispute according to the legislation. Waqf is not just a religious issue or for life people, but for the social and individual problems. Therefore, there are some things that put forward, such that the endowments allow for potential dispute, the validity of the act donating (waqf), and dispute resolution that can be reached through deliberation to reach consensus, if not successful, the dispute can be resolved through mediation, arbitration, and or court
\end{abstract}

\begin{abstract}
Abstrak: Tulisan ini akan membahas mengenai potensi dan sengketa perwakafan menurut peraturan perundang-undangan. Wakaf bukan sekadar masalah keagamaan atau masalah kehidupan seseorang belaka. Melainkan juga merupakan masalah kemasyarakatan dan individu secara keseluruhan. Oleh karena itu ada beberapa hal yang dikemukakan, diantaranya bahwa dalam wakaf memungkinkan adanya potensi sengketa, sah tidaknya perbuatan mewakafkan, dan penyelesaian sengketa perwakafan yang dapat ditempuh melalui musyawarah untuk mencapai musyawarah mufakat, jika tidak berhasil, sengketa dapat diselesaikan melalui mediasi, arbitrase, dan atau pengadilan.
\end{abstract}

Kata kunci: Wakaf, sengketa, bukum, legal, arbitrase.

\section{Pendahuluan}

Dalam sejarah kehidupan ummat Islam wakaf punya peran yang sangat penting dalam mengembangkan kegiatan sosial, ekonomi dan kebudayaan masyarakat Islam. Selain itu wakaf juga memfasilitasi kegiatan pendidikan disegala bidang ilmu pengetahuan. Pada masa awal kekuasaan Islam wakaf telah dikembangkan sedemikian rupa sehingga menjadi salah sumber kesejahteraan masyarakatnya.. Kebiasaan ini diteruskan sampai sekarang oleh negara negara berpenduduk mayoritas Islam, dimana lembaga wakaf berkembang sangat maju dan mampu memberi manfaat yang besar, bukan hanya untuk ummat di negeri itu tapi juga ummat di negara lain. Hal ini karena ternyata wakaf mampu menjadi sarana pemberdayaan ekonomi yang cukup memadai bagi kesejahteraan masyarakat. ${ }^{1}$

Demikian pula dengan Indonesia, hukum perwakafan telah mengalami kemajuan yang cukup signifikan dengan lahirnya Undangundang Nomor 41 tahun 2004 tentang wakaf. Kehadirannya merupakan suatu yang dinanti nantikan oleh mereka yang selama ini menggeluti masalah perwakafan baik di lingkungan akademisi maupun praktisi.

Banyak hal baru yang pada peraturan perundangan sebelumnya belum diatur kini diatur dengan sangat sistematis, salah satu diantaranya adalah tentang harta benda wakaf yang dibatasi pada benda tidak bergerak saja, tetapi juga berupa benda bergerak seperti uang, logam mulia, surat berharga dan lain-lain. Hal ini

1 Achmad Junaidi dan Thobieb al Asyhar, Menuju Era Wakaf Produktif, Mumtaz Publishing, Depok, 2005, h. 32 . 
sekaligus sebagai gambaran langkah maju di bidang hukum perwakafan di Indonesia.

Berdasarkan perjalanan sejarah bangsa kita, kegiatan wakaf dikenal seiring dengan perkembangan dakwah Islam di Nusantara. Di samping melakukan dakwah Islam, para ulama pada masa itu juga sekaligus memperkenalkan ajaran Islam lainnya termasuk didalamnya wakaf. Hal ini terbukti dari banyaknya masjid-masjid yang bersejarah dibangun di atas tanah wakaf. Ajaran wakaf ini terus berkembang di bumi Nusantara, baik pada masa dakwah pra kolonial, masa kolonial, maupun pasca kolonial sampai pada masa Indonesia merdeka.

Ajaran wakaf ini mulai menyatu dalam kehidupan umat Islam di Nusantara pada masa itu. Hal ini terlihat dari kenyataan bahwa lembaga wakaf yang berasal dari agama Islam ini telah diterima (diresepsi) menjadi hukum adat bangsa Indonesia sendiri. Masa pemerintahan kolonial merupakan momentum kegiatan wakaf. Karena pada masa itu, organisasi keagamaan mulai tumbuh dan berkembang, baik melalui jalur pendidikan berupa sekolah, pondok pesantren maupun melalui tempat tempat ibadah seperti masjid semuanya merupakan swadaya dan berdiri di atas tanah wakaf.

Namun, perkembangan wakaf kemudian hari tak mengalami perubahan yang berarti. Kegiatan wakaf dilakukan terbatas untuk kegiatan keagamaan, seperti pembangunan masjid, mushalla, langgar, madrasah, perkuburan, sehingga kegiatan wakaf di Indonesia kurang bermanfaat secara ekonomis bagi rakyat banyak.

Kini sudah saatnnya Indonesia memiliki lembaga lembaga termasuk wakaf yang diharapkan memberdayakan ekonomi ummat secara optimal, agar dapat membantu mensejahterakan umat Islam.Apalagi saat ini kita sudah memiliki seperangkat peraturan perundang undangan yang diharapkan dapat mengakomodir secara formal proses perwakafan di Negara kita.

Dalam sejarahnya, wakaf merupakan instrumen maliyah, yang sebagai ajaran ia tergolong pada syariah yang bersifat sakral dan suci, tetapi pemahaman dan implementasi wakaf tersebut tergolong pada fiqh (upaya yang bersifat kemanusiaan); karena itu, bisa dipahami bahwa praktik dan realisasi wakaf tersebut terkait erat dengan realitas dan kepentingan umat di masingmasing negara muslim (termasuk Indonesia). 2

Di beberapa negara, wakaf secara serius dijadikan sebagai media untuk mensejahterakan rakyat di samping pendapatan negara yang lain. Kekekalan objek wakaf menjadi salah satu doktrin utama untuk melestarikan keberadaannya dan modifikasi pemanfaat yang bervariasi menjadi inovasi pemberdayaan harta wakaf sehingga tidak statis dan stagnan. Wakif mengalami perubahan bentuknya, tidak hanya wakif perorangan tetapi juga wakif lembaga (baca: badan hukum), yang dituntut kredibilitas dan akuntabilitasnya. Demikian pula dengan keberadaan nadzir yang profesional menjadi pilihan dan keniscayaan zaman modern sekarang ini dalam mengemban amanat untuk mengelola harta wakaf.

Keberadaannya wakaf didasarkan kepada ayat ayat al-Qur'an antara lain:

- surah al Hajj ayat 77:

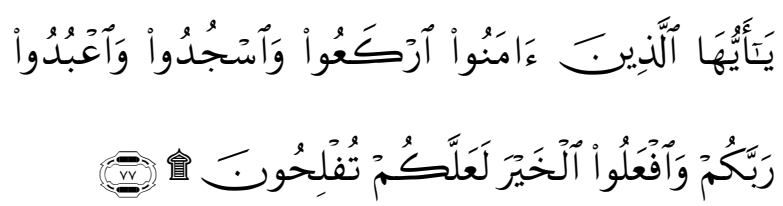

Artinya: "Hai orang-orang yang beriman, ruku'lah kamu, sujudlah kamu, sembahlah Tuhanmu dan perbuatlah kebajikan, supaya kamu mendapat kemenangan".- Ali Imran ayat 92

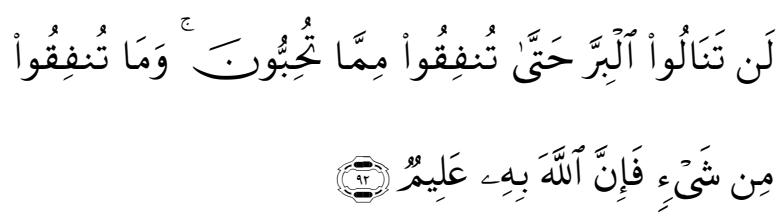

Kamu sekali-kali tidak sampai kepada kebajikan (yang sempurna), sebelum kamu menafkahkan sehahagian harta yang kamu cintai. dan apa saja yang kamu nafkahkan Maka Sesungguhnya Allah mengetahuinya.

Selain ayat-ayat al qur'an di atas dasar disyari'atkan wakaf ini adalah hadis: 
عن ابي هريرة ان رسول الهه صلى الله عليه وسلم قال: اذا

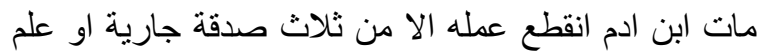
ينتفع به او ولد صالح يدعو اله (رواه مسلم)

Artinya: Dari Abu Hurairah ra., sesungguhnya Rasulullah SAW bersabda: Apabila anak adam (manusia) meninggal dunia, maka putuslah amalnya, kecuali tiga perkara: shadaqah jariyah, ilmu yang bermanfaatdan anak shaleh yang mendoakan orang tuanya". (HR. Muslim)

Adapun penafsiran shadaqah jariyah dalam hadis tersebut adalah:

$$
\text { ذكره في باب وقف لانه فسر العلماء الصدقة الجارية بالوقف }
$$

Hadis tersebut dikemukakan di dalam bab wakaf, karena para ulama menafsirkan shadaqah jariyah dengan wakaf'. 2

Di Indonesia praktek perwakafan sudah dilakukan Sejak kedatangan Islam dengan didasarkan kepada paham yang dianut oleh sebagian besar masyarakat Islam Indonesia pada waktu itu, yakni berupa adat kebiasaan setempat. Pola pelaksanaan wakaf masih menggunakan kebiasaan-kebiasaan keagamaan seperti kebiasan melakukan perbuatan hukum perwakafan tanah secara lisan atas dasar saling percaya kepada seseorang atau lembaga tertentu. Selain itu ada pula kebiasaan yang memandang wakaf sebagai perbuatan amal shaleh yang mempunyai nilai mulia di hadapan Allah SWT. Tanpa harus melalui prosedur administratif, serta adanya anggapan bahwa harta wakaf itu milik Allah semata yang siapa saja tidak akan berani mengganggu gugat tanpa seizin Allah.

Anggapan dan kebiasaan di atas pada saat itu akhirnya berdampak kurang berkembangnya perwakafan di Indonesia. Bahkan tidak jarang pada akhirnya menimbulkan sengketa karena ketiadaan bukti tertulis dalam proses perwakafan tersebut. Sehingga tujuan dari kegiatan wakaf ini tidak sesuai dengan apa yang diinginkan. Padahal bagi masyarakat Indonesia yang tengah mengalami problema sosial menuntut akan kesejahteraan ekonomi, institusi wakaf dapat

\footnotetext{
2 Imam Muhammad Ismail al-Kahlani, tt, 87.
}

dijadikan sebagai salah satu alternatifnya. Oleh karena itu memberikan pemahaman yang lebih luas terhadap wakaf menjadi sangat diperlukan.

\section{Pengaturan Wakaf di Indonesia}

Masalah wakaf bukan sekadar masalah keagamaan atau masalah kehidupan seseorang belaka. Melainkan juga merupakan masalah kemasyarakatan dan individu secara keseluruhan yang mempunyai dimensi polymorphe secara indisipliner dan multi disipliner menyangkut masala sosial, ekonomi, kemasyarakatan bahkan politik. ${ }^{3}$ Oleh karena itu dituntut adanya pengaturan yang sistematis yang dikeluarkan oleh lembaga yang berwenang.

Masyarakat Islam di Indonesia patut bersyukur, walaupun bertahap pemerintah terus berusaha mengatur masalah wakaf ini. Ada beberapa peraturan perundangan yang dikeluarkan yang mengatur masalah wakaf ini. Misalnya dalam Undang Undang Pokok Agraria diatur dalam pasal 49 Jo. Pasal 5 dan pasal 14 yang menegaskan bahwa pemerintah memberikan hak milik kepada badan-badan yang bersifat keagamaan maupun badan-badan sosial, dengan jaminan akan mendapatkan perlindungan.

Demikian pula dengan dikeluarkan peraturan pemerintah No. 28 tahun 1977 yang lebih memberikan pemahaman bahwa perwakafan yang semula hanya merupakan ketentuan yang dikenal di dalam fikih Islam maka dengan adanya peraturan ini secara jelas ditegaskan bahwa wakaf adalah suatu lembaga keagamaan yang dapat dipergunakan sebagai salah satu sarana guna pengembangan kehidupan keagamaan, khususnya Islam di Indonesia.

Setelah lama dinantikan kini telah hadir Undang Undang Nomor 41 Tahun 2004 Tentang Wakaf. Hal ini sekaligus menggambarkan dukungan secara penuh oleh pemerintah terhadap perwakafan di Indonesia. Pengaturan ini juga merupakan salah satu upaya pemerintah agar wakaf dapat berkembang secara

3 Drs. H. Tauiq Hamami, Perwakafan tanah dalam politik bukum Agraria, PT. tata Nusa, Jakarta, h. 11. 
cepat dan dapat dijangkau oleh semua kalangan. Banyak perubahan yang dilakukan oleh undangundang ini kalau dibandingkan dengan peraturan sebelumnya.

Dinamika sosial, desakan publik dan perubahan paradigma berpikir yang semakin meluas sebagai salah satu motivasi lahirnya UU No. 41 tentang wakaf sebagai payung hukum yang lebih kuat berskala nasional. UU tersebut mendefiniskan bahwa:"Wakaf adalah perbuatan hukum wakif untuk memisahkan dan/atau menyerahkan sebagian harta benda miliknya untuk dimanfaatkan selamanya atau untuk jangka waktu tertentu sesuai dengan kepentingannya guna keperluan ibadah dan/atau kesejahteraan umum menurut syariah". ${ }^{4}$

Definisi ini tergolong definisi yang cukup longgar dan mengakomodasi perbedaan pendapat dikalangan ahli fiqh dan mempertimbangkan pengembangan objek wakaf demi kemaslahatan umat.

Beberapa catatan yang dapat dikemukakan adalah:

1) Fleksibilitas bentuk objek wakaf dalam Inpres sebenarnya sudah mengakomodir semua pandangan ahli fiqh, tetapi tertutupi oleh pandangan hierarkhi terhadap pandangan hukum di Indonesia, bahwa Peraturan Pemerintah (PP) lebih tinggi dari pada Intruksi Presiden (Inpress), sehingga dengan lahirnya UU tersebut fleksibilitas tersebut lebih kuat payung hukumnya;

2) Kendala fanatisme madzhab yang kuat di akar rumput dalam meyakini objek wakaf adalah tanah (yang ia termasuk barang tak bergerak), sehingga implementasi belum berjalan mulus;

3) Durasi waktu dimunculkan mengakomodasi madzhab Maliki yang menafsirkan adanya wakaf temporal;

4) Kata "keperluan umum" dirubah "kesejahteraan umum" mencerminkan sasaran final wakaf adalah masyarakat

4 UU No. 41 Tahun 2004 tentang Wakaf pasal 1 ayat (1). dapat menikmati wakaf sebagai salah satu media yang bisa mensejahterakannya;

5) Kata "Agama Islam" atau "Islam" dirubah menjadi "Syariah".5

Undang Undang wakaf adalah manefestasi dari pendapat para ahli fikih mengenai wakaf. Dalam fikih disebutkan wakaf dinyatakan sah apabila telah terpenuhi rukun dan syaratnya. Rukun wakaf menurut fiqh ada 4 (empat) macam, yaitu

1) Waqif (orang yang mewakafkan),

2) Mauquf 'alaih (pihak yang diserahi wakaf), (3)

3) Mauquf (harta yang diwakafkan),

4) Shighat atau iqrar (pernyataan atau ikrar wakif sebagai suatu kehendak untuk mewakafkan). ${ }^{6}$

Masing masing rukun wakaf dalam fikih haruslah memenuhi syarat. Untuk Waqif (orang yang mewakafkan) disyaratkan haruslah harus mempunyai kecakapan hukum atau kamalul ahliyah (legal competent) dalam membelanjakan hartanya (tasharruf al-mal). Kecakapan tersebut meliputi 4 kriteria ${ }^{7}$, yaitu: (1) Merdeka; (2) Berakal sehat, (3) Dewasa (baligh), (4) tidak dibawah pengampuan. ${ }^{8}$

Mauquf 'alaih (orang yang diberi amanat wakaf), Mauquf 'alaih dalam literatur fiqh kadang diartikan orang yang diserahi mengelola harta wakaf, yang sering disebut nadzir, kadang juga diartikan peruntukan harta wakaf. Bila diartikan mauquf 'alaih sebagai nadzir, dalam literatur figh kurang mendapat porsi pembahasan yang detail oleh para ahli fiqh yang terpenting adalah keberadaan mauquf uf 'alaih mampu mewujudkan peruntukan benda wakaf (makna lain dari mauquf 'alaih). Hal ini terpengaruh oleh

5 Lihat M. Dawam Rahardjo (2004). "Menegakkan Syariat Islam di Bidang Ekonomi" dalam Adiwarman Azwar Karim. Bank Islam: Analisis Fiqih dan Keuangan. (Jakarta: Rajawali Press), hlm. xx.

6 Asy-Syarbini (t.t.). Mughni al-Mubtaj, (Kairo: Mushthafa Halabi), Juz II, hlm. 376.

7 Ibid.

8 Di bawah pengampuan menurut al-Bajuri meliputi 2 jenis yaitu (1) orang yang berhutang, dan (2) orang yang sedang sakit parah (penyakit cenderung mematikan). Lihat al-Baijuri (t.t.). Hasyiyah alBaijuri. (Beirut: Dar al-Fikr), II, hlm. 44. 
unsur tabarru' (kebaikan) yang meliputi peruntukan ibadah dan sosial (umum) kecuali yang bertentangan dengan Islam (ideologi) dan maksiat. Pengaruh lain adalah karena pemahaman bahwa wakaf termasuk akad sepihak yang tidak membutuhkan adanya qabul dan salah satu pendapat boleh hukumnya wakaf kepada diri sendiri.

Berkenaan dengan keyakinan nadzir, menurut Nawawi ${ }^{9}$ sah hukumnya wakaf kepada kafir dzimmi dengan 2 syarat, (1) peruntukan objek wakaf yang diamanatkan kepada nadzir tidak berupa ibadah bagi muslim, seperti wakaf Qur'an kepada nadzir kafir dzimmi, dan (2) manfaat benda wakaf oleh nadzir tidak untuk kepentingan keyakinan si kafir daimmi seperti wakaf untuk pembangunan gereja yang difasilitasi oleh nadzir kafir dzimmi.

Rukun yang ketiga adalah Mauquf (Harta Benda Wakaf). Perbincangan figh mengenai benda wakaf, bertolak pada, pertama, jenis harta, apakah benda bergerak atau tidak bergerak, atau bisa keduanya. Madzhab Syafi'iyah dan Hanbaliyah tergolong konservatif dengan hanya membolehkan harta tak bergerak sebagai objek wakaf. Sementara Hanafiyah dan Malikiyah cenderung membolehkan wakaf harta bergerak. Perbedaan ini muncul dari perbedaan menafsirkan apakah yang diwakafkan adalah dzat benda atau manfaat benda. Bila dzat benda maka cenderung benda tidak bergerak yang ternyata jumlah jenisnya sedikit, sedangkan bila manfaat benda cenderung benda bergerak yang jumlah jenisnya sangat banyak.

Keterkaitan antara status kepemilikan wakif terhadap benda wakaf setelah diwakafkan berimplikasi pada kewenangan atas perlakuan wakif terhadap benda wakaf tersebut yang oleh hadis riwayat umar memuat tiga tindakan yaitu dijual, dihibahkan dan diwariskan.

Terhadap hal tersebut Abu Hanifah menyatakan bahwa harta wakaf masih milik wakif, maka wakif boleh memperlakukan apa saja terhadap harta wakaf seperti menjual,

\footnotetext{
9 Nawawi (t.t.). al-Raudhah. (Beirut: Dar al-Kutub al-
} 'Ilmiah), Juz IV, hlm. 379. menghibahkan, dan mewariskan termasuk mengagunkan harta benda wakaf. Berbeda dengan Hanafi, Maliki sekalipun menyatakan bahwa harta wakaf milik wakif, tetapi wakif tidak punya hak untuk mendayagunakan harta wakaf secara pribadi dalam bentuk apapun. Sedangkan Syafii dan Hambali menyatakan putusnya kepemilikan harta wakaf dengan wakif sehingga wakif terputus haknya terhadap harta wakaf. Kelanggengan atau keabadian objek wakaf yang terkait erat dengan objek wakaf yang bergerak. Oleh karena itu mewakafkan harta bergerak harus melekat dengan harta tak bergerak seperti wakaf alat pertanian terkait dengan sawah, dan sebagainya. ${ }^{10}$

Rukun yang terakhir adalah Shighat (pernyataan atau ikrar wakif) adalah pernyataan penyerahan harta benda wakaf oleh wakif. Semua madzhab menyatakan bahwa wakaf adalah akad tabarru' yaitu transaksi sepihak yang sah sebagai suatu akad yang tidak memerlukan kabul dari pihak penerima dan dicukupkan dengan ijab si wakif. Akad tidaklah menjadi syarat dalam akad wakaf.

Definisi akad disini adalah suatu bentuk perbuatan hukum (tasharruf) yang mengakibatkan adanya kemestian penataan kepada apa yang dinyatakan dari kehendak perbuatan hukum itu oleh pihak yang berkepentingan, kendatipun pernyataan itu dari sepihak saja. Akad dalam pengertian kesepakatan dari dua belah pihak yang berkehendak melakukan suatu perikatan digambarkan dengan ijab dan qabul seperti yang terjadi dalam jual beli, sewa menyewa, dan sebagainya, sehingga tidaklah berlaku dalam pengertian akad wakaf ${ }^{11}$.

Di samping penjelasan tersebut di atas, alKabisi lebih dahulu mempertanyakan apakah wakaf termasuk akad yang menimbulkan tasharruf (perbuatan hukum) yang menimbulkan prestasi akibat hukum yang telah disetujui atau al-iqa' (pelimpahan) yang tidak menimbulkan

\footnotetext{
${ }^{10}$ Tuti A. Najib \& Ridwan al-Makassary (ed.) (2006). Wakaf, Tuhan dan Agenda Kemanusiaan: Studi tentang Wakaf dalam Perspektif Sosial di Indonesia. (Jakarta: CRCS UIN Syahid), hlm. 39.

11 Abu Zahrah. Muhadharat fi al-Waqf, hlm. 51-52.
} 
akibat hukum, hanya pelimpahan atau penyerahan yang instrinsik di dalamnya adalah amanat dan tanggung jawab untuk menjalankannya. Ia cenderung berpendapat bahwa wakaf merupakan akad al-'iqa' (pelimpahan) karena fokus wakaf adalah pendayagunaan yang sifatnya sosial dengan perspektif kebutuhan sosial juga, bukan kontraktual. ${ }^{12}$

UU No. 41 tahun 2004 tentang Wakaf mengakomodir rukun dan syarat wakaf ini dengan istilah unsur unsur wakaf yang terdiri dari:wakif, nazir, harta benda wakaf, ikrar wakaf, peruntukan harta benda wakaf dan jangka waktu wakaf.

Unsur yang pertama adalah wakif. Syarat wakif dalam undang undang ini tidak jauh berbeda dengan uraian figh, hanya UU No. 41 tahun 2004 menambahkan syarat (1) tidak terhalang melakukan perbuatan hukum, dan (2) pemilik sah harta benda wakaf.

Dua syarat tersebut diakomodasi dari berbagai pendapat ulama fiqh. Mengenai benda wakaf, di Indonesia terjadi perluasan makna. Pada mulanya terbatas pada tanah yang termasuk kategori harta tak bergerak. Dalam UU No. 41 tahun 2004 membolehkan wakaf dengan harta bergerak maupun harta tak bergerak. Kategori yang dijelaskan dalam undang-undang tersebut antara lain: (1) Benda Tidak bergerak, meliputi (a) hak atas tanah, (b) bangunan/bagian bangunan yang berdiri di atas tanah tersebut, (c) tanaman/benda lain yang berkaitan dengan tanah, (d) hak milik atas satuan rumah susun, (e) benda tidak bergerak sesuai syariah dan UU; (2) Benda bergerak, seperti uang, logam mulia, surat berharga, kendaraan hak atas kekayaan intelektual, hak sewa dan benda bergerak sesuai syariah dan UU, termasuk mushaf, buku, kitab.

Dengan demikian pengaturan harta benda wakaf yang tidak hanya sebatas benda tidak bergerak, tetapi juga memungkinkan dilakukannya wakaf terhadap benda bergerak berupa uang dan sejenisnya (giro, saham dan surat berharga lainnya. Selain itu karena wakaf ini

12 Al-Kabisi. Hukum Wakaf, hlm. 95. merupakan sebuah perbuatan hokum, maka berpotensi menimbulkan sengketa. Sehingga di dalam Undang-undang No. 41 tahun 2004 ini di atur pula tata cara penyelesaian sengketa wakaf.

Dari segi akadnya, wakaf memang diakui sebagai akad sepihak dan termasuk akad tabarru', yang tidak membutuhkan qabul dari nadzir. Tetapi terhadap akad tersebut harus disikapi secara hati-hati Nadzir harus dilihat profil, komitmen, reputasi, kredibilitas, kapabilitas dan terpopuler adalah track record (rekam jejak) sehingga akuntabilitas publiknya dapat dipertanggungjawabkan.

Hal terpenting pula terkait dengan akad adalah dimungkinkan timbulnya sengketa yang memerlukan pembuktian untuk keabsahan sehingga dipersyaratkan adanya (1) dokumen dan (2) saksi. Keduanya bukan menjadi rukun tetapi alat bukti yang harus ada dan dapat menguatkan keberadaan adanya akad (penyerahan) wakaf. Hal inilah yang sering terjadi di masyarakat, dan ini diduga adalah pengaruh madzhab Syafi' 'i. ${ }^{13}$

\section{Potensi Sengketa di bidang Perwakafan dan Penyelesainnya}

Sengketa adalah kata lain dari konflik. Ada ahli yang menyamakan pengertian antara sengketa dengan konflik ada pula yang membedakannya. Bagi yang menyamakannya sengketa atau konflik diartikan dengan suatu interaksi yang bersifat antagonistis (berlawanan, berseberangan, bertentangan), atau hubungan antara dua pihak atau lebih 14yang memiliki/merasa memiliki sasaran yang tidak sejalan. Bagi yang membedakannya, maka yang dimaksud dengan konflik adalah keadaan dimana para pihak menyadari/mengetahui tentang adanya perasaan tidak puas, sedangkan sengketa adalah dimana konplik tersebut dinyatakan dimuka umum atau melibatkan pihak ketigaSebagai makhluk sosial, manusia senantiasa berinteraksi dengan sesamanya.

13 Juhaya S. Praja. Perwakafan di Indonesia, h. 3.

14 Abdurrahman, Peranan Hukum Dalam penanggulangan Konflik Sosial, Banjarmasin, 2002, h. 8-9). 
Oleh karena itu agar interaksi ini berjalan dengan baik, maka dibutuhkan pengaturan baik dalam peraturan perundang undangan maupun bentuk pengaturan lainnya. Segala ketentuan dalam aturan itu pada dasarnya haruslah di taati oleh semua pihak yang terlibat di dalamnya. Semua harus dapat dilaksanakan dengan sukarela atau i'tikad baik, namun dalam kenyataannya hal tersebut seringkali dilanggar, sehingga pada akhirnya berpotensi memunculkan sengketa di antara para pihak.

Pada dasarnya setiap sengketa yang muncul termasuk sengketa perwakafan terdapat tiga aspek, yakni:

a. Aspek yuridis, yakni adanya perbedaan antara das sein dan das sollen, atau perbedaan antara kenyataan yang terjadi dengan norma yang seharusnya dijalankan. Sehingga sessuatu yang terjadi itu sebenarnya merupakan hal yang secara normatif seharusnya tidak boleh terjadi atau tidak boleh dilakukan.

b. Aspek sosiologis, yakni adanya suatu fakta yang membuat suatu pihak merasa dirugikan oleh pihak lawan yang membuat/melakukan fakta/kejadian itu, dan tidak mau secara suka rela mengganti kerugian atau menyelesaikan dengan damai dan masing-masing pihak tidak mau mengalah atau mengalah salah satunya.

c. Aspek psikologis, yakni bahwa pada hakikatnya sengketa itu terjadi antara sesama manusia dalam kapasitas apapun. Rasa emosional manusia inilah yang memunculkan adanya sengketa ${ }^{15}$.

Oleh karena setiap sengketa mempunyai 3 (tiga aspek, maka setiap sengketa memiliki 3 (tiga) sifat yang melekat padanya, yang melambangkan unsur-unsur tersebut, yaitu:

1) Sifat formal, yakni sifat sengketa yang melekat pada nilai atau norma hukum yang mengaturnya, mungkin karena nilai norma hukumnya kurang jelas, terdapat beberapa

15 A. Mukti Arto,Mencari Keadilan, (Kritik dan Solusi Terhadap Praktek Peradilan Perdata, Pustaka Prlajar, Yogyakarta, 2001, h. 38) aturan yang berbeda beda atau saling berlawanan, adanya keragu raguan atau ketidakpastian hukum, atau belum adanya aturan dan lain sebagainya.

2) Sifat substansial, yakni sifat sengketa yang melekat pada objek sengketa atau benda yang disengketakan, mungkin bendanya berbeda atau berlainan dan sebagainya.

3) Sifat emosional, yakni sifat sengketa yang melekat pada manusianya, mungkin karena perasaan (yang meliputi etika dan estitika), pemikirannya (anggapan, penilaian, pandangan, penguraian, analisis, cara berpikir dan keyakinannya)keinginan atau kepentingan yang berbeda atau berlawanan

Demikian pula dengan kegiatan perwakafan yang ada di tengah kehidupan masyarakat Islam di Indonesia, Selama ini potensi munculnya sengketa dalam bidang perwakafan antara lain adalah:

Pertama yang berkaitan dengan wakif, ikrar, nazhir serta saksi. Biasanya menyangkut sah tidaknya perbuatan mewakafkan. Dalam hal ini sengketa yang muncul dipicu oleh antara lain adanya pengingkaran terhadap ikrar wakaf, adanya keinginan untuk menarik kembali harta yang telah diwakafkan. Hal ini di dorong antara lain oleh makin langkanya tanah/makin tingginya harga (harta benda wakaf), menipisnya kesadaran beragama, adanya kesan wakif menelantarkan ahli waris, adanya sikap serakah ahli waris atau adanya ketidaktahuan ahli waris wakif terhadap wakaf yang dilakukan si wakif.

Kedua, yang berkaitan dengan bayyinah (alat bukti administrasi harta benda wakaf) seperti akta ikrar wakaf, akta pengganti akta ikrar wakaf, alat bukti kepemilikan harta benda wakaf atau hal-hal lain yang berhubungan dengan pencatatan dan pendaftaran perwakafan. Keberadaan dokumen (sertifikat) dan saksi menjadi persoalan terpenting yang tidak bisa diabaikan, mengingat kultur sosial yang mengatasnamakan ibadah (tabarru') semuanya serba lisan. Sengketa yang muncul kemudian diharapkan tidak muncul- dapat mengajukan dokumen dan saksi sebagai alat bukti untuk 
menyelesaikan sengketa, meskipun proses penyelesaiannya mungkin tidak sederhana.

Ketiga, yang berkaitan dengan pengelolaan dan pemanfaatan harta benda wakaf, seperti penyimpangan penggunaan harta wakaf oleh nazhir dan lain-lain. ${ }^{16}$

Apalagi dengan diundangkan Undang Undang Nomor 41 tahun 2004 tentang Wakaf yang memperluas jenis harta benda wakaf tidak hanya benda tidak bergerak seperti tanah sebagaimana peraturan perundangan sebelumnya tetapi juga berupa benda bergerak seperti uang, logam mulia, surat berharga dan lain-lain. ${ }^{17} \mathrm{Hal}$ ini makin menambah poteni munculnya sengketa bidang perwakafan ini.

Istilah sengketa biasanya selalu dihubungkan dengan konflik. Ada orang yang menyamakan kedua istilah tersebut, namun ada juga yang membedakannya. Bagi mereka yang membedakannya maka disebutkan:

a) Konflik adalah keadaan dimana para pihak menyadari atau mengetahui tentang adanya perasaan tidak puas tersebut.

b) Sengketa adalah keadaan dimana konflik tersebut dinyatakan di muka umum atau dengan melibatkan pihak ketiga. ${ }^{18}$

Dalam kosa kata Inggris dua istilah itu konflik (conflict) dan sengketa (dispute) adalah dua kata yang mengandung pengertian tentang: "adanya perbedaan kepentingan di antara dua pihak atau lebih". Tetapi kedua kata tersebut dapat dibedakan yang mana konflik adalah menggambarkan sebuah situasi dimana dua pihak atau lebih dihadapkan pada perbedaan kepentingan, kemudian pihak yang merasa dirugikan telah menyatakan tidak puas atau keprihatinannya kepada pihak yang dianggap

16 Taufiq Hamami, Perwakaan Tanah (Dalam Politik Hukum Agraria Nasional), PT. Tatanusa Jakarta, 2003, h. 170-171).

17 Lihat pasal 16 Undang Undang Nomor 41 tahun 2004 tentang Wakaf.

18 Kriekhoff, 1993, Mediasi (Tinjauan dari Segi Antropologi) Dalam T.O. Ihrohmo (ed) Antropologi Hukum Sebuah Bunga Rampai, Jakarta, Yayasan Obor Indonesia, h. 223. sebagai penyebab kerugian atau pihak lain maka ini dinamakan sengketa. ${ }^{19}$

Ini berarti sengketa adalah merupakan kelanjutan dari konflik, yang mana sebuah konflik akan berubah menjadi sengketa apabila tidak dapat terselesaikan. Konflik dapat diartikan "pertentangan" diantara para pihak untuk menyelesaikan masalah yang kalau tidak diselesaikan dengan baik dapat mengganggu hubungan di antara mereka. Sepanjang para pihak menyelesaikan masalah tersebut dengan baik, maka sengketa tidak akan terjadi. Namun bila terjadi sebaliknya; para pihak tidak dapat mencapai kesepakatan mengenai solusi pemecahan masalahnya; maka sengketalah yang timbul. ${ }^{20}$

Penyelesaian sengketa dalam perkembangannya sangat berkaitan erat dengan perkembangan yang terjadi dalam masyarakat. Terlebih lagi pada masyarakat yang semula masyarakat agraris mulai berkembang kearah masyarakat industri. Hal ini menjadi penyebab terjadinya benturan-benturan nilai. Nilai-nilai tradisional yang dipegang teguh oleh generasi dulu mulai luntur, sedangkan nilai-nilai baru (modern) belum sepenuhnya terbentuk dan diterima.

Dalam keadaan seperti ini, cara penyelesaian sengketa tradisional dengan bantuan pemuka masyarakat, kepala adat dan pemuka agama, atau sesepuh keluarga cenderung terbatas pada sengketa keluarga, perkawinan, dan warisan.

Pada kelompok di mana sistem tradisional ini melembaga dan membudaya, peranan figurfigur ini dianggap tidak efektif lagi, apalagi untuk menyelesaikan sengketa modern. Terjadi perubahan yang berdampak bergesernya nilai yang tumbuh dan berkembang di masyarakat.

Perubahan-perubahan sosial, ekonomi, politik, dan budaya ini akan terus berlangsung.

19 Siti Megadianti Adam dan Takdir Rahmadi, 1997, Sengketa dan Penyelesaiannya, (Bulletin Musyawarah Nomor 1 Tahun I, Jakarta: Indonesian Center For Environmental Law), h. 1.

${ }^{20}$ Rahmadi Usman, 2003, Pilihan Penyelesaian Sengketa di Luar Pengadilan, Bandung, PT. Citra Aditya Bakti, h. 2. 
Hal tersebut perlu diikuti perkembangan sistem untuk menangani benturan nilai dari perbedaan pendapat. Sistem tersebut diharapkan mampu mengurangi kemungkinan munculnya sengketa, ataupun menyelesaikan dengan cepat, tepat, dan memuaskan para pihak yang bersengketa yang ada di masyarakat. ${ }^{21}$

Pada prinsipnya pihak pihak yang bersengketa menghendaki penyelesaian dengan cara cepat, tepat, adil dan murah. Hal ini telah menjadi asas umum dalam penyelesaian sengketa. Demikian pula dengan sengketa wakaf. Dalam pasal 62 Undang Undang Nomor 41 tahun 2004 tentang Wakaf disebutkan bahwa :

1) Penyelesaian sengketa perwakafan ditempuh melalui musyawarah untuk mencapai musyawarah mufakat.

2) Apabila penyelesian sengketa sebagaimana di maksud pada ayat (1) tidak berhasil, sengketa dapat diselesaikan melalui mediasi, arbitrase, atau pengadilan.

Penyelesaian sengketa wakaf ditempuh dengan beberapa tahapan yang dilakukan secara stratifikatif. Dari isi pasal 62 ayat (2) tersebut diketahui bahwa cara penyelesaian pertama yang direkomendasikan oleh peraturan perundangan ini adalah musyawarah. Hal ini dilakukan dengan mempertemukan pihak pihak yang bersengketa untuk mencari jalan keluar terbaik dalam rangka menghentikan sengketa dimaksud.

Pada umumnya, pihak-pihak yang bersengketa lebih suka menyelesaikan sendiri secara musyawarah dengan pihak yang bersangkutan tanpa melibatkan pihak ketiga. Hal ini dapat bergantung pada i'tikad baik (goodwill) dari kedua belah pihak serta tingkat kerumitan sengketa itu sendiri. ${ }^{22}$

Musyawarah diartikan dengan berunding, berembuk, yakni pembahasan bersama dengan maksud mencapai keputusan atas penyelesaian masalah bersama. ${ }^{23}$ Apabila masing-masing pihak punya tekad yang sungguh sungguh untuk

21 Suyud Margono, 2000, ADR Alternative Dispute Resolution dan Arbitrase (Proses Pelembagaan dan Aspek Hukum), Jakarta, Ghalia Indonseia, h. 13.

22 A. Mukti Arto, op. Cit., h. 32.

23 Ibid., h. 67. menyelesaikan sengketa, maka ia akan terselesaikan dengan mudah, Karena kesungguhan pihak pihak sangat menentukan berhasil tidaknya penyelesaian sengketa.

Musyawarah akan menghasilkan keadilan yang sesungguhnya (substansial justist) yang dapat dirasakan oleh para pihak yang bersengketa, bukan sekadar keadilan formal (formal justist) saja. ${ }^{24}$

Namun jika sengketa itu tidak berhasil diselesaikan sendiri oleh para pihak sendiri, maka dibutuhkan adanya pihak ketiga untuk membantu menyelesaikannya. Atau dengan cara mediasi. Menurut penjelasan pasal 62 ayat (2) bahwa yang dimaksud dengan mediasi adalah penyelesaian sengketa dengan bantuan pihak ketiga (mediator) yang disepakati oleh para pihak yang bersengketa. Dengan demikian penyelesaian dengan mediasi memerlukan proses perundingan para pihak yang dibantu oleh mediator. Adapun mediator adalah pihak yang bersifat netral dan tidak memihak, yang berfungsi membantu para pihak dalam mencari berbagai kemungkinan penyelesaian sengketa 25 .

Mediasi adalah upaya penyelesaian sengketa yang dilakukan oleh para pihak melalui perundingan dengan bantuan pihak lain atau pihak ketiga yang netral (mediator) guna mencari dan menemukan bentuk-bentuk penyelesaian yang dapat disepakati bersama oleh para pihak. Mediator tidak mempunyai kewenangan memutus atau memaksakan suatu bentuk penyelesaian sngketa. Keputusan selama perundingan berlangsung ada di tangan para pihak yang terlibat sengketa tersebut. ${ }^{26}$ Fungsi mediator adalah sebagai penengah dan ia haruslah netral. Karena jika mediator bersikap netral, maka akan lahir ikatan berdasarkan kepercayaan.

Selain itu mediator juga bertujuan menolong dua belah pihak untuk mencapai kesepakatan dengan tetap netral dan menjamin kerahasiaan,

24 Ibid., h. 70

25 Lihat Peraturan Mahkamah agung RI, No. 2 tahun 2003 tentang Prosedur Mediasi di pengadilan Mahkamah Agung RI.

26 Takdir Rahmadi, Op. Cit, h. 264. 
para pihak tidak merasa kehilangan, walaupun harus mengurangi hal yang menguntungkan mereka untuk mencapai kesepakatan. ${ }^{27}$ Proses mediasi melibatkan pihak ketiga baik perorangan maupun dalam bentuk lembaga independen yang bersifat netral dan tidak memihak, yang akan berfungsi sebagai "mediator". Sebagai pihak yang netral, independen dan tidak memihak yang ditunjuk oleh para pihak (baik langsung maupun melalui lembaga mediasi), mediator ini berkewajiban untuk melaksanakan tugas dan fungsinya berdasarkan pada kehendak dan kemauan para pihak. Walau demikian ada satu pola yang umum dan dapat diikuti dan pada umumnya dijalankan oleh mediator dalam rangka penyelesaian sengketa para pihak.

Sebagai suatu pihak di luar perkara yang tidak memiliki kewengan memaksa, mediator ini berkewajiban untuk bertemu atau mempertemukan para pihak yang bersengketa guna mencari masukan mengenai pokok persoalan yang dipersengketakan oleh para pihak. Berdasarkan informasi yang diperoleh, baru kemudian mediator dapat menentukan duduk perkara, kekurangan dan kelebihan dari masing masing pihak yang bersengketa, untuk selanjutnya menyusun proposal penyelesaian, yang kemudian dikomunikasikan kepada para pihak secara langsung. Mediator harus mampu menciptakan situasi dan kondisi yang kondusif bagi terciptanya kompromi di antara kedua belah pihak yang bersengketa untuk memperoleh hasil yang saling menguntungkan (win win)28.

Dalam hal mediasi tidak berhasil menyelesaikan sengketa wakaf, maka sengketa tersebut dapat di bawa kepada badan arbitrase syari'ah. Ini merupakan cara penyelesaian ketiga. Adapun pengertian arbitrase menurut Undang Undang Nomer 30 tahun 1999 adalah:"cara penyelesaian sengketa perdata di luar peradilan umum yang didasarkan perjanjian tertulis oleh para pihak yang bersengketa". Penyelesaian

27 Linda R. Siregar, 1994, Settling Disputes - Conflict Resolution in Business, Families, and The Legas Sistem, San Fransisco: Westview Press, h. 27.

28 Gunawan Wijaya dan Ahmad Yani,, op. cit., h. 34. dengan arbitrase ini memiliki beberapa kelebihan, antara lain dijamin kerahasiaan para pihak, karena tidak ada publikasi, Cepat dan hemat, para pihak bisa memilih, tempat, waktu, hukum yang digunakan dan prosedur sederhana dan putusannya final and binding.

Sebagai sebuah pranata penyelesaian sengketa, arbitrase ini didahului adanya perjanjian atau kesepakatan dari para pihak baik yang dibuat para pihak sebelum timbul sengketa maupun dalam bentuk perjanjian tersendiri yang dibuat para pihak setelah timbul sengketa.

Objek perjanjian arbitrase (sengketa) yang bisa diselesaikan melalui arbitrase (domain of arbitration) adalah pertama sengketa perdata bidang perdagangan yang terdiri dari perniagaan, perbankan, keuangan, investasi, industri dan Hak atas kekayaan Intelektual. Kedua, Sengketa mengenai hak (yang menurut hukum dan perundang-undangan) dikuasai sepenuhnya oleh para pihak, termasuk di dalamnya sengketa wakaf.

Di dalam tradisi Islam telah di kenal badan hakam yang sama pengertiannya dengan arbitrase, Hakam itu sendiri bersumber dari syari'at Islam yang putusannya didasarkan pada islah. Masalah yang ditanganinya terbatas pada masalah al amwal (harta benda). Pemantapan badan bakam dalam sejarah hukum Islam terlebih lagi berlangsung pada saat fiqib muamalah berkembang dengan pesat.

Dasar pemberlakuan lembaga arbitrase dalam Islam dapat di sandarkan pada teks hukum yang ada dalam al Qur'an surat al Hujarat ayat 9:

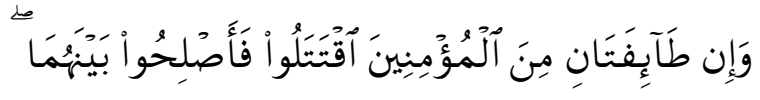

Artinya:'Dan kalau ada dua golongan dari mereka yang beriman itu berperang hendaklah kamu damaikan antara keduanya.

Lembaga arbitrase yang berwenang untuk menyelesaikan sengketa wakaf ini menurut penjelasan pasal 62 ayat (2) adalah arbitrase syari'ah. Dan di Indonesia sudah terbentuk Basyarnas (Badan Arbitase Syari'ah Nasional) yang merupakan perangkat dari organisasi Majelis Ulama Indonesia. Kewenangan dari 
Basyarnas ini adalah menyelesaikan sengketa dalam masalah muamalah/perdata yang menyangkut bidang perdagangan, industri, keuangan, jasa dan lain lain. ${ }^{29}$

Sebagai arbitrase institusional, arbitrase syari'ah ini diharapkan mampu merealisasikan hukum Islam dalam kehidupan konkrit untuk menyelesaikan sengketa yang timbul dalam hubungan perdagangan, industri, keuangan, jasa dan lain lain (termasuk wakaf) yang mana para pihak sepakat secara tertulis menyerahkan penyelesaiannya kepada lembaga arbitrase Islam tersebut. $^{30}$

Dalam hal badan arbitrase syari'ah tidak berhasil menyelesaikan sengketa, maka sngketa tersebut dapat dibawa ke pengadilan. Pengadilan dalam hal ini adalah merupakan tumpuan harapan terakhir pihak pihak yang terlibat sengketa wakaf.

Sebagai lembaga sosial pengadilan bertugas melayani masyarakat di bidang hukum dan keadilan serta memberikan bantuan sesuai dengan apa yang mereka perlukan dalam batasbatas yang dibenarkan dan dianjurkan oleh hukum. Di samping melaksanakan tugas pokoknya untuk menerima, memeriksa dan mengadili serta menyelesaikan setiap perkara/ sengketa yang diajukan kepadanya, termasuk sengketa wakaf.31Pengadilan yang dimaksud dalam hal ini berdasarkan penjelasan pasal 62 ayat (2) Undang Undang No. 41 tahun 2004 tentang wakaf adalah Pengadilan Agama.

Sebagai salah satu pranata dalam memenuhi hajat hidup anggota masyarakat untuk menegakkan hukum dan keadilan Peradilan Agama mengemban tugas khusus pada bidangbidang keperdataan Islam. Dimana ia berfungsi untuk menerima, memeriksa dan memutus ketetapan hukum antara pihak-pihak yang bersengketa dengan putusan yang dapat menghilangkan permusuhan berdasarkan bukti-

29 Zulkifli, Ensiklopedi Islam, Jakarta, PT. Ikhtiar, 1996, h, 163.

30 Komar Karta Atmaja, Beberapa Masalab Penerapan ADR di Indonesia, Citra Aditya Bakti, Bandung, 2001, h. 41.)

31 A. Mukti Arto, op. Cit., h. 14-15). bukti dan keterangan dengan tetap mempertimbangkan dasar-dasar hukum yang ada.

Peradilan Agama adalah peradilan Islam di Indonesia, sebab dari jenis jenis perkara yang menjadi kewenangannya seluruhnya adalah jenis perkara yang didasarkan kepada agama Islam. Selain itu Peradilan Agama juga dikhususkan bagi mereka yang beragama Islam dan/atau mereka yang menyatakan diri tunduk kepada hukum Islam. Dalam menjalankan fungsinya Peradilan Agama berpegang kepada beberapa sumber hukum, baik formal maupun materiel. Untuk hukum materiel dim lingkungan Peradilan Agama yang juga merupakan Peradilan Islam selama ini berpegang kepada beberapa peraturan perundang-undangan yang salah satunya beserta peraturan pelaksananya.

Dalam menjalankan tugas dan fungsi Peradilan Agama dipegang oleh Pengadilan Agama untuk tingkat pertama dan Pengadilan Tinggi Agama untuk tingkat banding, yang masing masing mempunnyai wewenang 32 yang diatur oleh undang-undang. Wewenang dimaksud antara lain meliputi kewenangan terhadap jenis perkara yang disebutkan dalam pasal 49 dan 50 Undang-undang No. 7 tahun 1989 tentang Peradilan Agama yang telah di amandemen dengan Undang undang Nomer 3 tahun 2006 yang berbunyi: "Pengadilan Agama bertugas dan berwenang memeriksa, memutus dan menyelesaikan di tingkat pertama antar orang orang yang bergama Islam di bidang:
a. Perkawinan
b. Kewarisan
c. Wasiat
d. Hibah
e. Wakaf
f. Zakat
g. Infak
h. Sedekah

32 (Kata Wewenang atau kekuasaan pada umumnya dimaksudkan adalah kekuasaan absolut. Dalam berbagai peraturan perundang-undangan kekuasaan absolut sering di singkat dengan kata kekuasaan saja. Drs. H.A. Basiq Djalil, SH, MH, Peradilan Agama di Indonesia, Jakarta, Kencana, 2006, h. 149. h. 140)) 
i. Ekonomi syari'ah

Hal ini adalah karena masalah pelaksanaan perwakafan ini di dalam kehidupan masyarakat sehari-hari pelaksanaannya lebih banyak dilaksanakan secara syari'at Islam, maka sudah barang tentu politik hukum nasional menggariskan bahwa badan peradilan yang berwenang untuk menyelesaikan perselisihan perselisihan yang terjadi di dalamnya adalah wewenang Peradilan Agama.

Sebagai lembaga yang berwenang menyelesaikan sengketa wakaf pengadilan agama dituntut untuk dapat menyelesaikan dengan seadil adilnya dengan didasarkan kepada hukum yang berlaku.

\section{Penutup}

Ada beberapa hal yang dikemukakan pada bagian penutup yang juga merupakan kesimpulan dari tulisan ini..

Pertama karena masalah wakaf bukan sekadar masalah keagamaan atau masalah kehidupan seseorang belaka. Melainkan juga merupakan masalah kemasyarakatan dan individu secara keseluruhan, sehingga tidak menutup kemungkinan adanya potensi sengketa.

Kedua Selama ini potensi munculnya sengketa dalam bidang perwakafan antara lain adalah yang berkaitan dengan wakif, ikrar, nazhir serta saksi, yang biasanya menyangkut sah tidaknya perbuatan mewakafkan. Ada pula yang berkaitan dengan bayyinah (alat bukti administrasi harta benda wakaf) dan yang berkaitan dengan pengelolaan dan pemanfaatan harta benda wakaf. Ketiga Penyelesaian sengketa perwakafan ditempuh melalui musyawarah untuk mencapai musyawarah mufakat, jika tidak berhasil, sengketa dapat diselesaikan melalui mediasi, arbitrase, dan atau pengadilan.

\section{Daftar Pustaka}

Abdurrahman, Peranan Hukum Dalam penanggulangan Konflik Sosial, Banjarmasin, 2002.

Achmad Junaidi dan Thobieb al Asyhar, Menuju Era Wakaf Produktif, Mumtaz Publishing, Depok, 2005.
Adijani al-Alabij, Drs. SH., Perwakafan Tanah di Indoneia Dalam Teori dan Praktek, Cet-IV, PT. Raja Grafindo Persada, Jakarta, 2002.

Antonio, Muhammad Syafi'I, Bank Syariah wacana Ulama dan Cendekia, Tazkia Institut, Jakarta, 1991.

Asy-Syarbini, Mughni al-Mubtaj, (Kairo: Mushthafa Halabi), Juz II. tt

Daud Ali, Muhammad, Sistem Ekonomi Islam, Zakat dan Wakaf, UI Press, 1988.

Departemen Agama, Al-Qur'an dan Terjemahnya, Jakarta, 1999.

Farida Prihatni et. Al, Hukum Islam (Zakat dan Wakaf) Teori dan Prakteknya di Indonesia, Papas Sinar Sinanti dan badan penerbit Fakultas hukum UI, Jakarta, 2005.

Komar Karta Atmaja, Beberapa Masalab Penerapan ADR di Indonesia, Citra Aditya Bakti, Bandung, 2001.

Komar Karta Atmaja, Beberapa Masalab Penerapan ADR di Indonesia, Citra Aditya Bakti, Bandung, 2001.

Linda R. Siregar, Settling Disputes - Conflict Resolution in Business, Families, and The Legas Sistem, San Fransisco: Westview Press, 1994.

Mawardi, al., al-Hawi al Kabir, Tahqiq Dr. Muhammad Mathraji, Dar al fik, Juz IX, Beirut, 1994.

Mediasi (Tinjauan dari Segi Antropologi) Dalam T.O. Ihrohmo (ed) Antropologi Hukum Sebuab Bunga Rampai, Jakarta, Yayasan Obor Indonesia

Mukti Arto, A., Mencari Keadilan, (Kritik dan Solusi Terbadap Praktek Peradilan Perdata, Pustaka Prlajar, Yogyakarta, 2001.

M. Dawam Rahardjo, Menegakekan Syariat Islam di Bidang Ekonomi, dalam Adiwarman Azwar Karim. Bank Islam: Analisis Fiqih dan Keuangan. (Jakarta: Rajawali Press), 2004

Rahmadi Usman, Pilihan Penyelesaian Sengketa di Luar Pengadilan, Bandung, PT. Citra Aditya Bakti, 2003.

Rahmat Djatmika, H, Wakaf dan Masyarakat Serta Aplikasinya (Aspek-aspek Fundamental), Mimbar hukum, No. 7 tahun III, jakarta, 1992. 
Siti Megadianti Adam dan Takdir Rahmadi, Sengketa dan Penyelesaiannya, Bulletin Musyawarah Nomor 1 Tahun I, Jakarta: Indonesian Center For Environmental Law, 1997.

Su'ud Muhammad, Abu As., Risalatu fi Jawari Waqfi an Nuqud, Dar Ibn Hazm, Beirut, 1997

Suyud Margono, ADR Alternative Dispute Resolution dan Arbitrase (Proses Pelembagaan dan Aspek Hukum), Jakarta, Ghalia Indoneeia, 2000.
Taufiq Hamami, Drs. H., Perwakafan Tanah Dalam Politik Hukum Agraria, PT. Tata Nusa, Jakarta, 2003.

Tim Depag, Fiqih Wakaf, Depag RI, Jakarta, 2007.

Tuti A. Najib \& Ridwan al-Makassary (ed.) Wakaf, Tuban dan Agenda Kemanusiaan: Studi tentang Wakaf dalam Perspektif Sosial di Indonesia. (Jakarta: CRCS UIN Syahid), 2006.

Wahbah Az-Zuhaili, DR., al Figh al Islami wa Adillatubu, Damsyik, Darl al Fikr, 1985.

Yahya Harahap, Beberapa Tinjauan mengenai sistem Peradilan dan Penyelesaian Sengketa, Citra Aditya, Bandung, 1997.

Zulkifli, Ensiklopedi Islam, Jakarta, PT. Ikhtiar, 1996. 